\title{
Kasvitautien torjunta luomuherukan viljelyssä
}

\author{
Pirjo Kivijärvi ${ }^{1)}$ ja Päivi Parikka ${ }^{2)}$ \\ 1) MTT Ympäristöntutkimus, Ekologinen tuotanto, Karilantie 2 A, 50600 Mikkeli, \\ pirjo.kivijarvi@mtt.fi \\ 2) MTT Kasvintuotannon tutkimus, Kasvinsuojelu, 31600 Jokioinen, paivi.parikka@mtt.fi
}

\section{Johdanto}

Luonnonmukainen herukanviljely on laajentunut voimakkaasti viime vuosina ja on jo saavuttanut luomumansikan viljelypinta-alan. Maamme luomumustaherukan viljelyala on tällä hetkellä 272 ha, mikä on noin $15 \%$ mustaherukan viljelyalasta. Luomuviljelyssä on pääasiassa mustaherukkaa, muita herukoita viljellään vähän.

Kasvinsuojeluongelmat ovat luomuherukan viljelyssä usein merkittävä este viljelyn onnistumiselle. Kasvitaudit voivat aiheuttaa suuria sato- ja laatutappioita, etenkin viljeltäessä puna- ja valkoherukkaa. Myös tuholaisten aiheuttamat vioitukset ja satotappiot ovat olleet merkittäviä.

Herukoiden tärkeimmät sienitaudit ovat varistetauti (Drepanopeziza ribis) ja harmaalaikku (Septoria ribis). Varistetauti on merkittävä puna- ja valkoherukalla, harmaalaikkua esiintyy kaikilla herukkalajeilla. Tutkimusten mukaan variste- ja harmaalaikkutauti aiheuttavat punaherukalla merkittäviä sadonalennuksia, ellei tauteja torjuta. Lehdistötautien merkitystä mustaherukan sadontuotolle ollaan vasta selvittämässä.

Lehtilaikkutautien luonnonmukaisista torjuntakeinoista on hyvin vähän julkaistuja tutkimustuloksia saatavilla. Tällä hetkellä kuparioksikloridi on luvanvaraisesti sallittu lehtilaikkutautien torjuntaa luomumarjanviljelyssä, mikäli kasvustoa uhkaa välitön tuhoutuminen. Mm. ruotsalaisissa luomuherukan viljelyohjeissa sitä suositellaan käytettäväksi suoranaisena torjuntatoimenpiteenä. Myös erilaisia kasviperäisiä keitteitä ja uutteita suositellaan käytettäväksi sekä ennaltaehkäisevänä että suorana torjuntana lehtilaikkutauteja vastaan, mutta tutkittua tietoa näiden tehosta ei juurikaan ole saatavilla. MTT:n Ekologisen tuotannon vastuualueella on selvitetty kolmen vuoden ajan herukan lehtilaikkutautien torjuntamahdollisuuksia luomupuna- ja valkoherukalla.

\section{Aineisto ja menetelmät}

Lehtilaikkutautien torjuntaa luomuviljelyssä selvitettiin vuosina 1999-2001 valkoherukalla ja vuonna 2001 punaherukalla MTT:n Ekologisen tuotannon vastuualueella Mikkelissä. Valkoherukkakenttä on perustettu vuonna 1992. Tuolloin kentälle istutettiin viljelijöiltä kerättyjä Valkean Hollantilaisen eri kantoja sekä tervetaimituotannossa olleet Valkea Hämäläinen - ja Valkea Jüterbog-lajikkeet. Kentällä on myös muutama Blanka- ja Primus-lajikkeen pensas. Kasvustot on alasleikattu huhtikuussa 1997. Punaherukkakenttä on perustettu vuonna 1990 ja alasleikattu huhtikuussa 1997. Kentällä ovat lajikkeet Punainen Hollantilainen, Roteswunder, Rubina, Fortun, Nortun ja Jotun.

Vuosina 1999-2000 valkoherukkakasvustoja käsiteltiin kuivatuista nokkosista valmistetulla nokkoskäytteellä tai naudanlantakompostista valmistetulla kompostiuutteella. Kontrollina oli käsittelemättömät pensaat. Vuonna 2001 itse valmistettu kompostiuute korvattiin nestekompostilla, jossa oli $50 \%$ naudanlantaa ja $50 \%$ meijerin herajätettä. Kokeisiin nestekompostin toimitti Suonenjoella toimiva Marjaosaamiskeskus. Vuonna 2001 punaherukkakasvuston käsittelyt olivat: nestekomposti, herajäte, nokkoskäyte ja kontrolli (käsittelemätön).

Vuosina 1999-2000 kompostiuute valmistettiin 2-3 vuotta vanhasta naudanlantakompostista ohjeella: 51 kompostilantaa / 201 vettä. Nokkoskäyte valmistettiin ohjeella: 200 g kuivattua nokkosta (lähinnä lehtiä) / 101 vettä. Seoksia seisotettiin huoneenlämmössä kannellisessa astiassa viikko ennen ensimmäistä ruiskutusta ja kaksi viikkoa toista ruiskutusta varten. Ennen ruiskutuksia seokset siivilöitiin ja nokkoskäyte laimennettiin vedellä 1:10. Vuonna 2001 nokkoskäytettä seisotettiin viikko ennen ensimmäistä ruiskutusta, jonka jälkeen koko seos siivilöitiin ja säilytettiin suljetussa astiassa kylmiössä seuraavia ruiskutuksia varten. Ennen ruiskutuksia seos laimennettiin 1:5. Nestekomposti siivilöitiin ja laimennettiin vedellä 1:4 ennen ruiskutusta. Herajäte siivilöitiin ja laimennettiin vedellä 1:1. Sekä nestekomposti että herajäte säilytettiin suljetussa astiassa kylmiössä.

Vuosina 1999 ja 2000 valkoherukkakasvustot ruiskutettiin kaksi kertaa keväällä ja kaksi kertaa syksyllä. Kevätruiskutukset olivat viikon välein toukokuun lopulla ja kesäkuun alkupäivinä. Syksyllä kasvustot ruiskutettiin sadonkorjuun jälkeen, kun pensaiden lehdistä osa oli jo varissut. Syysruiskutuksilla pyrittiin edistämään lehtien hajoamista syksyn ja talven aikana. Vuonna 2001 sekä 
puna- että valkoherukkakasvustot ruiskutettiin neljä kertaa; ensimmäinen ruiskutus kukinnan alkaessa, toinen täyskukinnan aikaan, kolmas kukinnan päätyttyä ja neljäs ruiskutus kaksi viikkoa kolmannen ruiskutuksen jälkeen.

Lehtilaikkutautien esiintymistä kasvustossa seurattiin kasvukauden aikana tehdyin havainnoin. Elokuussa kasvustoista kerättiin lehtinäytteet, joista arvioitiin tautien ankaruus. Pensaiden sadot korjattiin pamputtamalla.

\section{Tulokset}

Harmaalaikkutaudin oireet ilmestyivät kasvustoon juhannuksen tienoilla. Varistetaudin oireet noin viikko tämän jälkeen. Vuonna 1999 torjuntakäsittelyt vähensivät jonkin verran tautien määrää valkoherukkapensaissa sekä kasvustohavaintojen että lehtitarkastusten perusteella, mutta erot olivat pieniä. Seuraavina vuosina ei tautisuudessa ollut eroja käsittelyjen välillä. Torjuntakäsittelyn saaneet pensaat antoivat hieman suurempia satoja kuin käsittelemättömät, mutta eri valkoherukkakannoista johtuen satovaihtelut olivat suuria myös käsittelyjen sisällä (Kuva 1.).

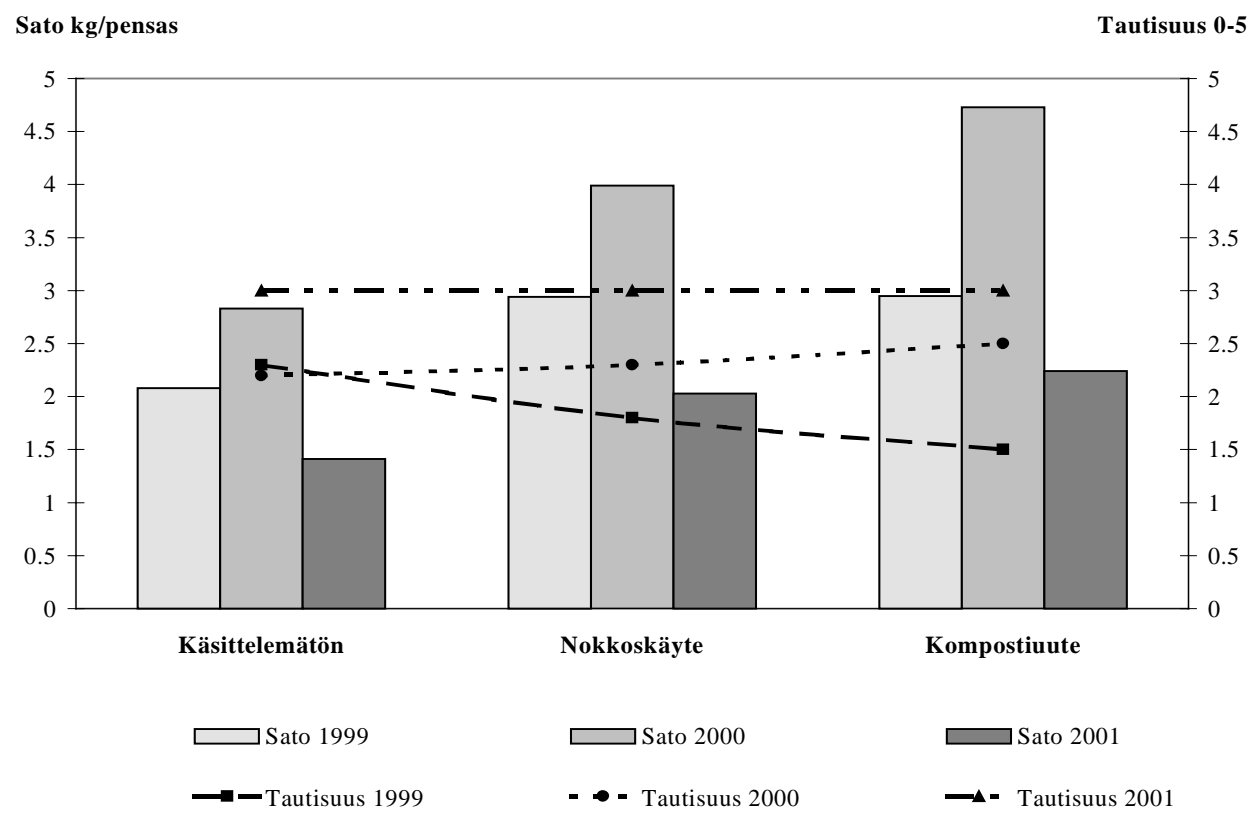

Kuva 1. Nokkoskäytteellä ja kompostiuutteella ruiskutetun valkoherukkakasvuston sato ja lehtilaikkutautien esiintyminen. Vuosina 1999-2000 kasvustot ruiskutettiin kukinnan alussa ja viikkoa myöhemmin sekä syksyllä kaksi kertaa sadonkorjuun jälkeen. Vuonna 2001 kompostiuute korvattiin nestekompostilla ja ruiskutukset olivat kukinnan alkaessa, täyskukinnan aikaan, kukinnan päätyttyä ja kaksi viikkoa kukinnan päätyttyä.

Vuonna 2001 kasvustohavaintojen ja lehtinäytteiden perusteella nokkoskäyte-, nestekomposti- ja herajätekäsittelyt eivät vähentäneet punaherukkakasvuston lehtilaikkutauteja käsittelemättömiin pensaisiin verrattuna. Pensaskohtaiset sadot vaihtelivat voimakkaasti lajikkeitten välillä sekä käsittelyjen sisällä, joten eri käsittelyjen välille ei saatu eroja (Kuva 2.). 


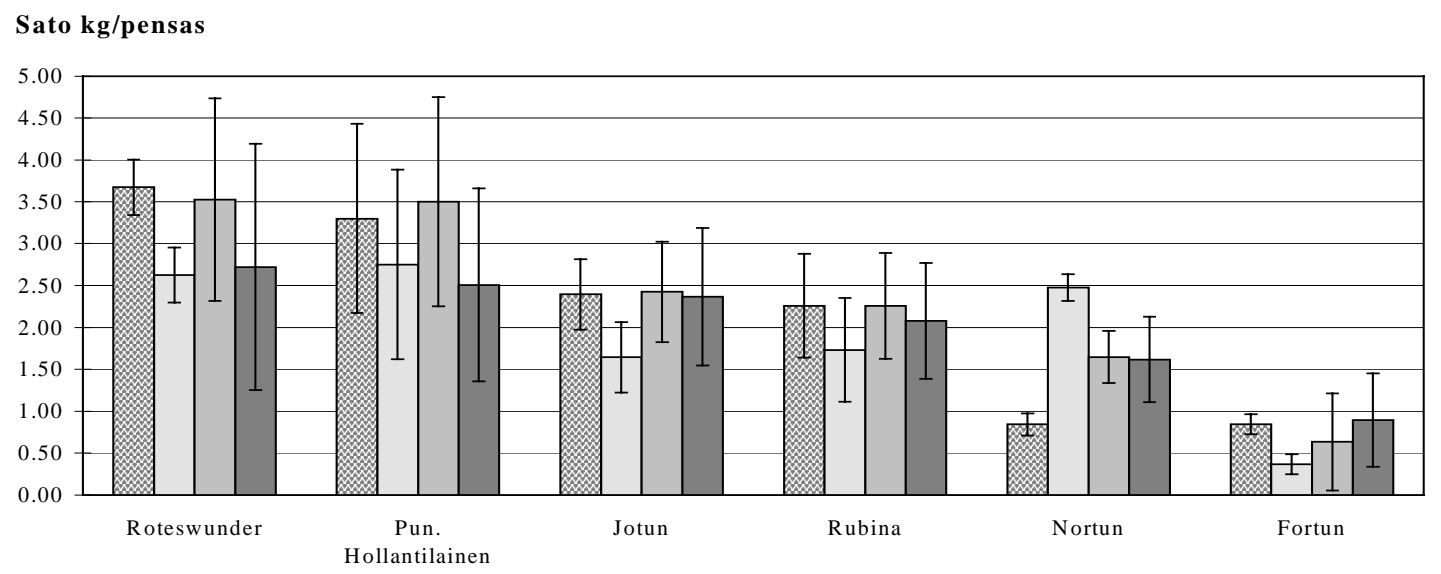

图 Kontrolli $\square$ Herajäte $\square$ Nestekomposti $\square$ Nokkoskäyte

Kuva 2. Punaherukkakasvuston pensaskohtaiset sadot lajikkeittain eri kasvustokäsittelyissä vuonna 2001. Käsittelyt tehtiin kukinnan alkaessa, täyskukinnan aikaan, kukinnan päätyttyä ja kaksi viikkoa kukinnan päätyttyä. Janat kuvaavat keskihajontaa.

\section{Tulosten tarkastelu}

Käyttämillämme ruiskutteilla ei saatu vähennettyä harmaalaikku- ja varistetautisaastuntaa valko- ja punaherukkakasvustoissa. Käyttämämme ruiskutusohjelma; kaksi ruiskutusta kukinnan aikaan ja kaksi ruiskutusta sadonkorjuun jälkeen tai neljä ruiskutusta alkaen kukinnan alussa ja päättyen pari viikkoa kukinnan jälkeen ei tautien torjunnan kannalta ole riittävä. Tavanomaisesti viljellyn herukan tautitorjunnan tehoa tutkittaessa on havaittu, että ennen ja jälkeen kukinnan tehtävien käsittelyjen lisäksi myös kukinnan aikaan on tehtävä ruiskutus, jotta voidaan estää tehokkaammin taudinaiheuttajien primäärisaastuntaa (Virolainen et al. 2001). Karisseiden lehtien käsittelyllä pyritään nopeuttamaan niiden hajoamista ja vähentämään siten lehdissä säilyviä taudinaiheuttajia. Omenaruven torjunnassa käytettävän syyskäsittelyn urealla on todettu vähentävän kehittyvien koteloitiöiden määrä selvästi (MacHardy 1996). Weltzien (1989) tutkimusten mukaan kompostiuutteen teho kasvitautien torjunnassa perustuu pääasiassa ennaltaehkäisevään torjuntaan.

Säätilalla on vaikutusta sekä tautien esiintymiseen että ruiskutustehoon. Vuonna 1999 toukokuun 4.-23. päivien välillä ei satanut lainkaan, mikä osaltaan viivästytti lehtilaikkutautien itiölentoa ja tautioireiden ilmenemistä kasvustoon. Kesä- ja heinäkuu olivat kaikkina koevuosina pitkäaikaisia keskiarvoja sateisempia. Vuonna 2001 kesä- ja heinäkuun sademäärä oli kaksinkertainen normaaliin verrattuna, joten olosuhteet olivat lehtilaikkutautien leviämiselle suotuisat. Sateita oli vuonna 2001 kolmen ensimmäisen ruiskutuskerran jälkeen usean päivän aikana, mikä voi osaltaan heikentää ruiskutteiden vaikutusta.

Koekentällämme olevien valkoherukkakantojen ja punaherukkalajikkeiden lehtilaikkutautien kestävyydessä havaittiin selviä eroja jo silloin, kun koekentät olivat vielä tavanomaisessa tuotannossa. Tuolloin punaherukkakentän torjuntaruiskutuksista huolimatta Rubina, Fortun ja Nortun saastuivat pahoin ja olivat jo elokuun puolivälissä lähes lehdettömiä (Dalman 1996). Myös vuosina 1999-2001 eri kantojen ja lajikkeiden taudinkestävyyserot tulivat esille, mutta eri ruiskutteiden hyödyllisyyttä luomuherukan tautitorjunnassa ei voitu kokeidemme perusteella osoittaa.

\section{Johtopäätökset}

Lehtilaikkutautien torjunta on vaikea haaste luomuherukanviljelyssä. Sekä variste- että harmaalaikkutauti talvehtivat pensaiden juurelle varisseissa lehdissä, joista itiöt vapautuvat keväällä sateiden yhteydessä saastuttamaan uusia lehtiä. Yksi torjuntakeino olisi varisseiden lehtien poistaminen tai peittäminen jollakin katteella, mutta isommilla viljelypinta-aloilla tällaisten toimenpiteiden toteuttaminen on liian työlästä. Varisseiden lehtien hajoamisen nopeuttaminen voisi olla helpommin toteutettavissa. 
Oikealla lajikevalinnalla voidaan osaltaan helpottaa tautiongelmaa. Iversenin et al. (2000) tutkimuksen mukaan luonnonmukaisesti viljeltyjen mustaherukkalajikkeiden sisältämien fenolisten yhdisteiden pitoisuuksissa oli merkitseviä eroja. Tiettyjen fenolisten yhdisteiden korkea pitoisuus korreloi positiivisesti varistetaudin, karviashärmän ja herukanvillaruosteen taudinkestävyyden kanssa. Korkeimmat fenolisten yhdisteiden pitoisuudet oli Intercontinental- ja Titania-lajikkeilla. Nämä lajikkeet olivat myös taudinkestävimpiä. Samat lajikkeet ovat osoittautuneet myös MTT:n luomumustaherukkalajikkeiden koekentällä herukanvillaruosteen kestäviksi.

Kasvitautien biologinen torjunta avomaalla on vielä varsin vähäistä ja torjunnan tehosta ei juurikaan löydy tutkittua tietoa. Kompostin tiedetään sisältävän mikrobistoa, joka kasvualustaan lisättäessä voi vähentää maassa eläviä, tauteja aiheuttavia sieniä, kuten Rhizoctonia solani- ja Pythium ultimum-sieniä sekä sienitautien aiheuttamia vioituksia useilla viljelykasveilla (Cook \& Baker 1983, Hoitink \& Fahy 1986, Schueler et al. 1989, De Ceuster \& Hoitink 1999). Kompostissa olevat, tautien torjunnan kannalta hyödylliset mikrobit voivat kuitenkin tuhoutua $\mathrm{mm}$. lämpötilan nousun seurauksena kompostointiprosessin aikana (De Ceuster \& Hoitink 1999). Tutkimuksin on myös todettu kompostiuutekäsittelyjen vähentävän $\mathrm{mm}$. perunaruton esiintymistä perunalla ja härmää ohralla (Weltzien 1989). Nestekompostin käytöstä ei löydy vastaavia tutkimustuloksia.

Käyttämistämme ruiskutteista juuri kompostiuutteella näyttäisi olevan suotuisissa olosuhteissa lehtilaikkutauteja ehkäisevä vaikutus. Tämän vuoksi kompostiuutetutkimuksia olisi syytä jatkaa tarkentaen uutteen valmistusprosessia ja ruiskutusohjelmaa siten, että huomioidaan paremmin ennaltaehkäisevä torjunta ja kasvukauden aikainen torjunta. Myös öljypohjaisten ruiskutteiden tehoa herukoiden lehtilaikkutauteihin tulisi tutkia.

\section{Kirjallisuus}

Cook, R.J. \& Baker, K.F. 1983. The nature and practice og biologiccal control of plant pathogens. Am. Phytopathol. Soc., St. Paul, MN. 540 pp.

Dalman, P. 1996. Löytyykö uusia viinimarjalajikkeita? Hedelmän- ja Marjanviljelijäin liitto ry:n 16. talviluentopäivät 13.-14.3.1996. Moniste.

De Ceuster, T.J.J. \& Hoitink, A.J. 1999. Using Compost To Control Plant Diseases. BioCycle Magazine 6: 61. Hoitink, H.A.J. \& Fahy, P.C. 1986. Basis for the control of soil-born plant pathogens with composts. Annu. Rev. Phytopathol. 24: 93-114.

Iversen, C.K., Lindhard Pedersen, H. \& Brandt, K. 2000. Phenolic compounds and disease resistance of 5 blackcurrant varieties in an organic growing system. $9^{\text {th }}$ Internationaler Erfahrungsaustauch über Forschungsergebnisse zum ökologischen Obstbau in Weinsberg: 87-90.

MacHardy, W.E. 1996. Apple Scab-Biology, Epidemiology and Management. 545 p. APS Press, Minnesota.

Schueler, C., Biala, J. \& Vogtmann, H. 1989. Antiphytopathogenic Properties of Biogenic Waste Compost. Agriculture, Ecosystems and Environment 27: 477-482.

Virolainen, J., Parikka, P. \& Aaltonen, M. 2001. Herukan tautitorjunnan tehoa voidaan parantaa. Puutarha \& kauppa 5(23): 4-5. ISSN 1239-8691.

Weltzien, H.C. 1989. Some Effects of Composted Organic Materials on Plant Health. Agriculture, Ecosystems and Environment 27: 439-446. 